\title{
EFEK IMUNOSTIMULAN EKSTRAK ETANOL DAUN SELEDRI TERHADAP MENCIT PUTIH JANTAN
}

\author{
Erjon $^{1 *}$, Rani Jovanka ${ }^{1}$, Sari Meisyayati ${ }^{1}$ \\ ${ }^{1}$ Sekolah Tinggi Ilmu Farmasi Bhakti Pertiwi Palembang \\ *E-mail : erjonplg@gmail.com
}

\begin{abstract}
The main active compound of celery is apigenin which is thought to have an immunostimulatory effect. This research aimed to evaluate the immunostimulatory effects of the ethanol extract of the celery leaf (Apium graveolens L.) using carbon clearance methods. The animal models used were albino mice male which were divided into 5 groups. Group I as negative control (tween 80\%), group II, III, IV were given ethanol extract of celery leaves at a dose of $125 \mathrm{mg} \mathrm{kgbw}, 250 \mathrm{mg} / \mathrm{kgbw}, 500 \mathrm{mg} / \mathrm{kgbw}$, and group V as the positive control (Stimuno Forte $\left.{ }^{\circledR}\right)$. The dosage is given orally in a single dose for 6 days. The results showed the administration of test preparations with a dose of 125 $\mathrm{mg} / \mathrm{kgbw}, 250 \mathrm{mg} / \mathrm{kgbw}, 500 \mathrm{mg} / \mathrm{kgbw}$ showed the phagocytosis constant value, half-life and leukocyte values were significantly different from negative control ( $\mathrm{p}<0.01$ ). Phagocytosis indices from test preparations with a dose of $125 \mathrm{mg} \mathrm{kgbw}, 250 \mathrm{mg} / \mathrm{kgbw}, 500 \mathrm{mg} / \mathrm{kgbw}$ also show values greater than 1 . It was concluded that the ethanol extract of celery leaves at a dose of $125 \mathrm{mg} \mathrm{kgbw}, 250 \mathrm{mg} / \mathrm{kgbw}, 500$ $\mathrm{mg} / \mathrm{kgbw}$ is as immunostimulants.
\end{abstract}

Keywords : Apium graveolens L, carbon clearance, immunostimulants.

\begin{abstract}
ABSTRAK
Senyawa aktif utama dari seledri adalah apigenin yang diduga mempunyai efek imunostimulan. Penelitian ini bertujuan untuk mengetahui efek imunostimulan ekstrak etanol daun seledri (Apium graveolens L.) menggunakan metode bersihan karbon. Hewan yang digunakan adalah mencit putih jantan. Hewan dibagi menjadi 5 kelompok. Kelompok I sebagai kontrol negatif (tween $801 \%$ ), kelompok II, III, IV diberi ekstrak etanol daun seledri dengan dosis masing-masing $125 \mathrm{mg} / \mathrm{kgbb}, 250 \mathrm{mg} / \mathrm{kgbb}, 500 \mathrm{mg} / \mathrm{kgbb}$ dan kelompok V sebagai kontrol positif (Stimuno Forte ${ }^{\circledR}$ ). Sediaan uji diberikan secara oral dengan dosis tunggal selama 6 hari. Hasil penelitian menunjukan pemberian sediaan uji dengan dosis $125 \mathrm{mg} / \mathrm{kgbb}, 250 \mathrm{mg} / \mathrm{kgbb}, 500 \mathrm{mg} / \mathrm{kgbb}$ menunjukan nilai konstanta fagositosis, waktu paruh dan nilai leukosit berbeda bermakna dengan kontrol negatif (p<0,01). Indek fagositosis dari sediaan uji dengan dosis $125 \mathrm{mg} / \mathrm{kbb}, 250 \mathrm{mg} / \mathrm{kgbb}, 500 \mathrm{mg} / \mathrm{kgbb}$ juga menunjukan nilai yang lebih besar dari 1. Disimpulkan bahwa ekstrak etanol daun seledri dengan dosis $125 \mathrm{mg} / \mathrm{kgbb}, 250 \mathrm{mg} / \mathrm{kgbb}$, $500 \mathrm{mg} / \mathrm{kgbb}$ bersifat sebagai imuniostimulan.
\end{abstract}

Kata Kunci : Apium graveolens L, bersihan karbon, imunostimulan 


\section{PENDAHULUAN}

Imunostimulan adalah senyawa yang dapat meningkatkan kerja sistem imun tubuh terhadap antigen yang masuk kedalam tubuh misalnya bakteri dan virus menyebabkan tubuh akan mudah terkena penyakit menular seperti influenza, diare, hingga HIV/AIDS. Obat imunostimulan banyak digunakan ketika sistem imun tubuh menurun. Senyawa ini sebagian besar bekerja dengan meningkatkan proliferasi sel dan menargetkan sel tujuan seperti makrofag, granulosit, limfosit $\mathrm{T}$ dan limfosit B.

Beberapa tanaman yang telah diuji sebagai agen imunostimulan yaitu meniran (Phyllanthus niruri L.) (Aldi et al, 2013), mengkudu (Morinda citrifolia) (Sasmito dkk, 2014), gambir (Uncaria gambier Roxb) (Zilhadia et al, 2012) dan tempuyung (Sonchus arvensis Linn) (Sukmayadi dkk, 2014).

Seledri merupakan salah satu tanaman obat potensial di Indonesia yang diduga memiliki efek dalam peningkatan sistem imun (imunostimulan). Seledri secara tradisional digunakan untuk mengobati rasa sakit pada rematik, nyeri pada lambung, melancarkan proses metabolisme dalam tubuh, membantu menjaga kekebalan tubuh, dan dapat memperbanyak air kencing (Rahayu, 2017). Kandungan utama dari eeledri adalah senyawa flavonoid seperti apigenin. Kandungan senyawa lainnya adalah saponin, tanin, alkaloid, minyak asiri, dan vitamin (A, B dan C) (Fitria dan Saputra, 2016).

Penelitian yang telah dilakukan pada daun seledri yaitu sebagai antioksidan, dimana antioksidan berperan penting dalam meningkatkan fungsi sel-sel imun dengan menangkal radikal bebas yang masuk kedalam tubuh. Selain itu seledri juga diteliti dapat berperan sebagai herbal antistress, dimana kondisi stress dapat menyebabkan aktifitas sel NK menurun (Khalifah dan Lutfiah, 2010).

Dari pendekatan tersebut perlu ditentukan efek imunostimulan dari ekstrak daun seledri dengan menggunakan metoda Carbon clearance, dimana metode tersebut digunakan untuk mengukur aktivitas sel-sel fagosit untuk membunuh organisme patogen yang masuk kedalam tubuh.

\section{METODE}

\section{Alat}

Seperangkat alat destilasi, rotary evaporator, neraca analitik $\left(\mathrm{HWH}^{\circledR)}\right.$, tabung eppendorf $\left(\right.$ Onemed $^{\circledR}$ ), plat tetes, vial, pipa kapiler (Neco $\left.80^{\circledR}\right)$, cawan penguap, pisau bedah (General Care ${ }^{\circledR}$ ), pipet mikro (Huawai ${ }^{\circledR}$ ), spektrofotometri UV-Vis $\left(\mathrm{Bel}^{\circledR}\right)$, kaca arloji $\left(\right.$ Normax $\left.^{\circledR}\right)$, haemocytometer (Marienfeld $^{\circledR}$ ) dan mikroskop (Olympus ${ }^{\circledR}$ ).

\section{Bahan}

Daun seledri (Apium graveolens L.), etanol destilat, tinta karbon $\left(\operatorname{Prapatan}^{\circledR}\right), \mathrm{NaCl} 0,9 \%$ b/v, tween 80, aquadest, fitofarmaka (Stimuno forte ${ }^{\circledR}$ ), $\mathrm{K}_{2}$ EDTA $10 \% \mathrm{~b} / \mathrm{v}$, reagen turk dan $\mathrm{Na}_{2} \mathrm{CO}_{3}$.

\section{Hewan Percobaan}

Hewan percobaan yang digunakan adalah mencit putih jantan sehat, galur swiss webster umur 2-3 bulan, bobot 20-30 gram sebanyak 25 ekor.

\section{Rancangan Penelitian}

Penelitian ini merupakan penelitian eksperimental. Pengujian efek imunostimulan dari ekstrak etanol daun seledri (Apium graveolens L.) dengan metode bersihan karbon dan penentuan jumlah leukosit. Hewan percobaan yaitu mencit putih jantan, digunakan sebanyak 25 ekor yang dibagi menjadi 5 kelompok secara acak. kelompok I sebagai kontrol negatif (Tween 80 1\%), kelompok II sebagai kontrol positif (Stimuno Forte ${ }^{\circledR}$ ) $6,5 \mathrm{mg} / \mathrm{kgbb}$, kelompok III diberi ekstrak daun seledri dosis 125 $\mathrm{mg} / \mathrm{kgbb}$, kelompok IV diberi ekstrak daun seledri dosis $250 \mathrm{mg} / \mathrm{kgbb}$, kelompok $\mathrm{V}$ diberi ekstrak daun seledri dosis $500 \mathrm{mg} / \mathrm{kgbb}$. Sedian uji diberikan peroral sesuai dengan kelompoknya masing-masing selama 6 hari. Pada hari ke-7 ditentukan konstanta fagositosis (K), waktu paruh eliminasi (t1/2), indek fagositosis (IF) dan jumlah leukosit.

\section{Pengambilan sampel}

Daun seledri (Apium graveolens L.) segar yang digunakan sebagai sampel diambil dari desa Bangke Kecamatan Kota Agung Kabupaten Lahat.

\section{Proses ekstraksi daun seledri}

Daun seledri (Apium graveolens L.) bersihkan dari pengotor, dicuci, dikering anginkan, dirajang kecil - kecil dan ditimbang sebanyak 500 gram, dimaserasi dengan etanol destilat. Selanjutnya maserat duapkan dengan didestilasi vakum dan dilanjutkan dengan rotary evaporator hingga didapatkan ekstrak kental.

\section{Perencanaan dosis sediaan uji}

Dosis yang digunakan mengacu pada penelitian sebelumnya (Sapri dkk, 2017), ekstrak daun seledri (Apium graviolens L.) yang digunakan pada mencit putih jantan dengan dosis $125 \mathrm{mg} / \mathrm{kgbb}, 250$ $\mathrm{mg} / \mathrm{kgbb}$ dan $500 \mathrm{mg} / \mathrm{kgbb}$. 


\section{Pengujian Aktivitas Imunostimulan}

Uji aktivitas imunostimulan dilakukan dengan metode bersihan karbon. Pada pengujian ini mencit dikelompokkan menjadi 5 kelompok, tiap kelompok terdiri dari 5 ekor. Tiap-tiap hewan percobaan diberikan sediaan uji satu kali sehari secara peroral selama 6 hari. Pada hari ke 7 mencit diinjeksi dengan suspensi karbon melalui vena ekor $0,2 \mathrm{ml} / 20 \mathrm{gbb}$, kemudian darah diambil pada menit ke 5 dan 15 melalui retro vena orbital dengan menggunakan pipa kapiler masing-masing sebanyak $50 \mu \mathrm{l}$ dan dilisis dengan $4 \mathrm{ml}$ natrium karbonat $1 \%$ dan diukur serapannya dengan UVVis pada panjang gelombang $675 \mathrm{~nm}$ (Necib , 2013). Di hitung konstanta fagositosis (K), waktu paruh karbon dalam darah $\left(\mathrm{t}_{1 / 2}\right)$ dan indek fagositoisi (IF) dengan menggunakan rumus :

Keterangan:

$$
K=\frac{I n_{O D 1}-I n_{O D 2}}{t_{2}-t_{1}}
$$

K : Konstanta fagositosis

In ODI : Absorban menit ke 5

In $\mathrm{OD} 2$ : Absorban menit ke 15

$\mathrm{t}_{1} \quad$ : Waktu awal (menit ke 5)

$\mathrm{t}_{2} \quad$ : Waktu akhir (menit ke 15)

Keterangan:

$$
t 1 / 2=\frac{0,693}{K}
$$

$\mathrm{t}_{1 / 2}$ : Waktu paruh eliminasi karbon

$\mathrm{K}$ : Konstanta fagositosis

$$
\mathrm{IF}=\frac{\text { Konstanta Fagositosis ekstrak }}{\text { Konstanta Fagosistosis kontrol negatif }}
$$

Keterangan

IF : Indek Fagosistosis

Perhitungan Jumlah Sel Leukosit

Ambil sebanyak $0,5 \mathrm{ml}$ darah segera tambahkan $\mathrm{K}_{2}$ EDTA $10 \%$. Sebanyak $10 \mu \mathrm{l}$ darah tambahkan 10 $\mu \mathrm{l}$ reagen turk masukkan kedalam tabung eppendorf, kocok selama 3 menit. Kemudian teteskan larutan pada kamar hitung haemocytometer. Biarkan cairan selama 2 menit agar leukosit mengendap. Kemudian leukosit dihitung menggunakan mikroskop elektron (Setianingsih dkk, 2017).

$$
\Sigma \mathrm{SDP}=\mathrm{NI} \times \mathrm{WP} \times 2,5
$$

Keterangan :

¿SDP : Jumlah sel darah putih

WP : Besarnya pengenceran

NI : Jumlah sel darah putih dalam 4 kotak
Data yang diperoleh dianalisis secara statistik menggunakan metode Anova One Way dilanjutkan dengan Uji Duncan dan Pearson Correlation.

\section{HASIL DAN PEMBAHASAN}

\section{Hasil}

Data hasil penelitian di sajikan dalam bentuk tabel dan gambar sebagai berikut :

Tabel 1. Rerata nilai konstanta fagositosis kelompok uji

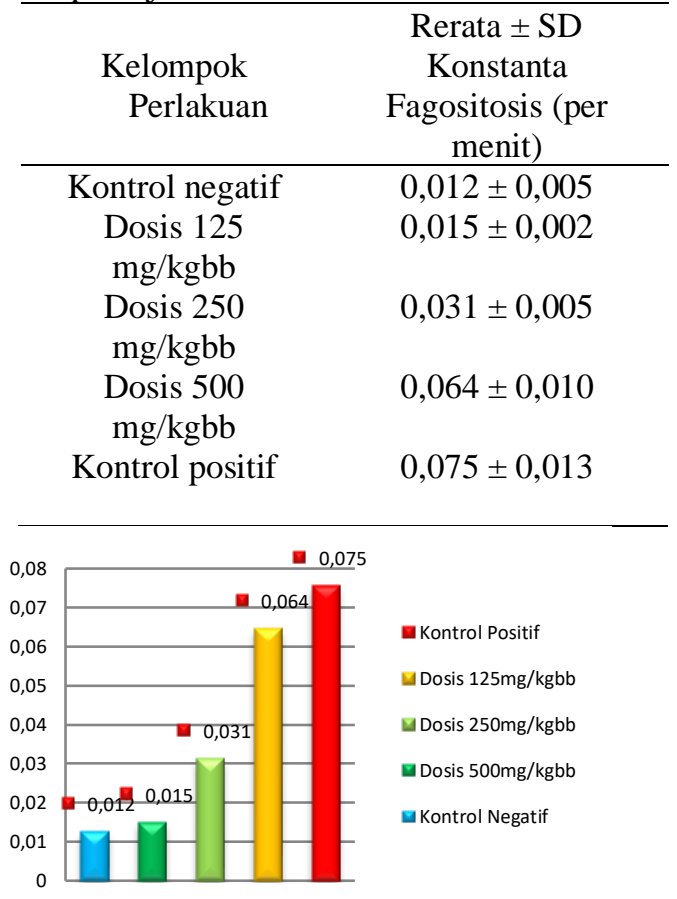

Gambar 1. Diagram batang rerata nilai Konstanta

\begin{tabular}{|c|c|}
\hline $\begin{array}{l}\text { Kelompok } \\
\text { Perlakuan }\end{array}$ & $\begin{array}{c}\text { Rerata } \pm \text { SD waktu } \\
\text { Paruh Eliminasi } \\
\text { Karbon (menit) }\end{array}$ \\
\hline Kontrol negatif & $60,10 \pm 18,54$ \\
\hline $\begin{array}{c}\text { Dosis } 125 \\
\mathrm{mg} / \mathrm{kgbb}\end{array}$ & $46,85 \pm 6,954$ \\
\hline $\begin{array}{l}\text { Dosis } 250 \\
\mathrm{mg} / \mathrm{kgbb}\end{array}$ & $22,68 \pm 4,251$ \\
\hline $\begin{array}{c}\text { Dosis } 500 \\
\mathrm{mg} / \mathrm{kgbb}\end{array}$ & $10,96 \pm 1,992$ \\
\hline Kontrol positif & $9,398 \pm 1,894$ \\
\hline
\end{tabular}
Fagositosis kelompok uji

Tabel 2. Rerata waktu paruh eliminasi karbon kelompok uji

\section{Analisis data}




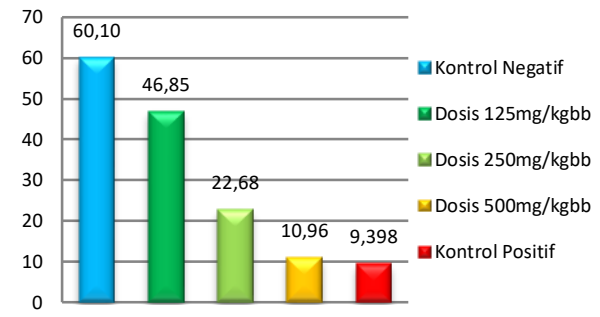

Gambar 2. Diagram batang rerata waktu paruh eliminasi karbon kelompok uji

Tabel 3. Nilai indek fagositosis kelompok uji

\begin{tabular}{cc}
\hline $\begin{array}{c}\text { Kelompok } \\
\text { Perlakuan }\end{array}$ & Indek Fagositosis \\
\hline $\begin{array}{c}\text { Dosis } 125 \\
\mathrm{mg} / \mathrm{kgbb}\end{array}$ & 1,25 \\
$\begin{array}{c}\text { Dosis } 250 \\
\mathrm{mg} / \mathrm{kgbb}\end{array}$ & 2,58 \\
$\begin{array}{c}\text { Dosis } 500 \\
\text { mg/kgbb }\end{array}$ & 5,00 \\
Kontrol Positif & 6,25 \\
\hline
\end{tabular}

Tabel 4. Rerata jumlah sel leukosit kelompok uji

\begin{tabular}{cc}
\hline $\begin{array}{c}\text { Kelompok } \\
\text { Perlakuan }\end{array}$ & $\begin{array}{c}\text { Rerata } \pm \text { SD Jumlah } \\
\text { Leukosit }\left(\mathrm{sel} / \mathrm{mm}^{3}\right)\end{array}$ \\
\hline Kontrol Negatif & $4100 \pm 50,00$ \\
Dosis 125 & $4700 \pm 180,2$ \\
mg/kgbb & \\
Dosis 250 & $5683 \pm 125,8$ \\
mg/kgbb & \\
Dosis 500 & $6033 \pm 202,0$ \\
mg/kgbb & \\
Kontrol Positif & $6916 \pm 104,0$ \\
\hline
\end{tabular}

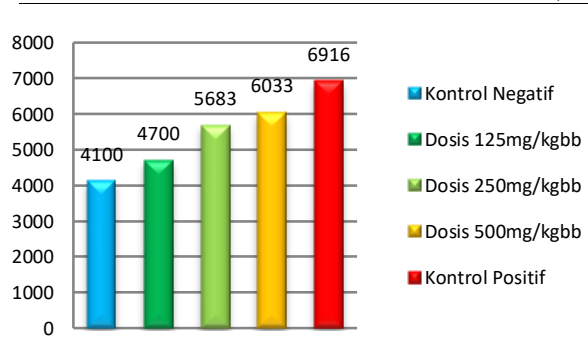

Gambar 3. Diagram batang rerata jumlah sel leukosit kelompok uji.

\section{Pembahasan}

Metode yang digunakan untuk penetuan efek imunostimulan dari ekstrak daun seledri (Apium graveolens L.) adalah metode bersihan karbon dan peningkatan jumlah sel leukosit. Dimana dengan metode ini dapat dilihat aktivitas fagositik. Aktivitas fagositik berpengaruh pada respon imun non spesifik yaitu pertahanan seluler fagosit. Ketika sel - sel fagosit mendeteksi adanya mikroorganisme/antigen maka akan terjadi proses kemotaksis yaitu pergerakan sel fagosit menuju antigen dan partikel tersebut akan melekat pada membran sel fagosit. Sel fagosit akan menyelubungi seluruh permukaan partikel asing, menelannya dan lisosom akan menghancurkan partikel asing tersebut. Parameter yang diamati yaitu konstanta fagositosis, waktu paruh karbon dalam darah, indek fagositois dan jumlah sel leukosit.

Sebagai antigen yang digunkan adalah tinta karbon, karena tinta karbon stabil dalam aliran darah dan tidak menyebabkan thrombosis. Pada saat karbon tinta diinjeksikan secara intravena maka karbon akan difagositosis oleh makrofag. Penurunan konsentrasi karbon di dalam darah diukur dengan spektofotometri UV-Vis panjang gelombang $675 \mathrm{~nm}$ (Aribi, 2013). Hasil yang didapatkan adalah adanya penurunan serapan darah spektofotometri UV-Vis dari menit 5 ke menit 15 yang menunjukkan semakin rendah nilai absorbansi maka konsentrasi karbon yang tinggal di dalam darah semakin sedikit. Hal ini karena adanya proses fagositosis karbon di dalam darah sehingga akan menurunkan nilai absorban. Perbedaan nilai absorban dari menit ke 5 dan 15 dapat dikonversi menjadi nilai konstanta fagositosis (Raj, 2015).

Hasil pengukuran rata-rata nilai konstanta fagositosis dapat dilihat pada tabel 4.1. Dari tabel tersebut nilai konstanta fagositosis dapat diurut dari yang terkecil ke yang terbesar adalah dari kelompok kontrol negatif, diikuti oleh kelompok perlakuan dosis $125 \mathrm{mg} / \mathrm{kgbb}, 250 \mathrm{mg} / \mathrm{kgbb}, 500$ $\mathrm{mg} / \mathrm{kgbb}$, dan kelompok kontrol positf yaitu berturut-turut $\quad 0,013 /$ menit, $\quad 0,015 /$ menit, 0,031/menit, 0,064/menit dan 0,076/menit. Peningkatan nilai konstanta fagositosis menujukan peningkatan kemampuan untuk melakukan fagoisitois. Dengan demikian ekstrak daun seledri dengan dosis 125, 250 dan $500 \mathrm{mg} / \mathrm{kgbb}$ mempunyai kemampuan untuk melakukan fagositosis.

Dari nilai konstanta fagositosis dapat dihitung waktu paruh eliminasi karbon. Berdasarkan hasil pengukuran diperoleh data ratarata nilai waktu eliminasi karbon (Tabel 4.2). Dari tabel tersebut dapat diurut dari yang terbesar ke yang terkecil kelompok kontrol negatif, kelompok perlakuan dengan dosis $125 \mathrm{mg} / \mathrm{kgbb}, 250$ $\mathrm{mg} / \mathrm{kgbbl} 500 \mathrm{mg} / \mathrm{kgbb}$ dan kontrol positif yaitu berturut-turut 60,105 menit, 46,856 menit, 22,680 menit, 10,968 menit dan 9,398 menit. Penurunan waktu eliminasi karbon di dalam darah menunjukan peningkatan kemampuan untuk melakukan fagositosis.

Pada penentuan jumlah leukosist sebagai antikoagulan digunakan larutan $\mathrm{K}_{2}$ EDTA $10 \%$. $\mathrm{K}_{2}$ EDTA dipilih karena menunjukkan stabilitas yang lebih baik dibandingkan antikoagulan yang lain karena darah dengan antikoagulan ini tidak menunjukkan ada perubahan $\mathrm{pH}$ pada darah. Reagen Turk digunkan untuk melisiskan sel lain 
selain leukosit dan gentian violet untuk memberi warna pada inti dan granula leukosit (Isnarni, 2010). Berdasarkan hasil pengukuran diperoleh data rata-rata jumlah sel leukosit (Tabel 4.3). Dari tabel tersebut jumlah sel leukosit terbesar adalah kelompok kontrol positif yaitu $6916 \mathrm{sel} / \mathrm{mm}^{3}$ dan jumlah sel leukosit terkecil adalah kelompok kontrol negatif yaitu $4100 \mathrm{sel} / \mathrm{mm}^{3}$ yang diikuti kelompok perlakuan dosis $125 \mathrm{mg} / \mathrm{kgbb}, 250$ $\mathrm{mg} / \mathrm{kgbb}$ dan $500 \mathrm{mg} / \mathrm{kgbb}$ yaitu $4700 \mathrm{sel} / \mathrm{mm}^{3}$, $5683 \mathrm{sel} / \mathrm{mm}^{3}$ dan $6033 \mathrm{sel} / \mathrm{mm}^{3}$. Peningkatan jumlah sel leukosit menunjukan adanya peningkatan imunitas. Semakin besar jumlah sel leukosit maka proses fagositosis meningkat dan eliminasi antigen semakin cepat.

Nilai indek fagositosis dari ekstrak 125, 250 dan $500 \mathrm{mg} / \mathrm{kgbb}$ serta kontrol positif adalah 1,25; 2,$58 ; 5,00$; dan 6,25. Nilai indeks fagositosis menunjukkan aktivitas fagositosis sel-sel fagositik terhadap partikel karbon sebagai antigen akibat pengaruh pemberian ekstrak daun seledri. Apabila nilai rata-rata indeks fagositosis lebih besar dari satu (IF >1) menunjukkan zat uji tersebut mempunyai kemampuan imunostimulan. Hal ini menunjukan ekstrak daun seledri dengan dosis 125 , 250 dan $500 \mathrm{mg} / \mathrm{kgbb}$ mempunyai kemampuan untuk meningkatkan sistem pertahanan tubuh terhadap aktivitas fagositosis sel fagositik

Hasil penelitian ini dianalisis menggunakan program aplikasi SPSS menggunakan uji one way anova dilanjutkan dengan uji duncan dan pearson correlations dengan kepercayaan 95\%. Pada kolom test of normality dan kolom test of homogenity of variances terlihat bahwa nilai konstanta fagositosis dan waktu paruh $(\mathrm{p}<0,05)$ yang berarti bahwa setiap kelompok perlakuan tidak berdistribusi normal dan tidak mempunyai varian yang sama. sedangkan pada nilai jumlah leukosit $(\mathrm{p}>0,05)$ yang berati bahwa setiap kelompok perlakuan berdistribusi normal dan mempunyai varian yang sama. Oleh karena itu nilai konstanta fagositosis dan waktu paruh perlu dilakukan transformasi data (log) untuk memperoleh data yang normal dan homogen. Transformasi data yang dipilih yaitu transformasi data logaritma karena data yang didapat bernilai positif dan tidak mempunyai varian yang sama (Ohyver, 2013). Setelah ditransformasikan pada kolom test of normality (Lampiran 16) dan kolom test of homogenity of variances (Lampiran 16) terlihat bahwa nilai konstanta fagositosis dan waktu paruh $(\mathrm{p}>0,05)$ yang berarti bahwa setiap kelompok perlakuan berdistribusi normal dan mempunyai varian yang sama. Berdasarkan hasil statistik one way annova menunjukkan bahwa nilai konstanta fagositosis, waktu paruh dan jumlah sel leukosit semua sediaan uji berbeda bermakna $(\mathrm{p}<0,05)$ maka dari itu diperlukan uji lanjutan menggunakan Duncan.

Berdasarkan hasil uji statistik Duncan dapat dilihat nilai konstanta fagositosis memiliki tiga subset dimana kelompok kontrol negatif dan ekstrak daun seledri dosis $125 \mathrm{mg} / \mathrm{kgbb}$ tidak berbeda nyata karena terletak pada subset yang sama. Sedangkan untuk ekstrak daun seledri dosis $250 \mathrm{mg} / \mathrm{kgbb}, 500 \mathrm{mg} / \mathrm{kgbb}$ dan kontrol positif berbeda nyata karena terletak pada subset yang berbeda. nilai waktu paruh juga memiliki 3 subset dimana kelompok kontrol positif dan ekstrak daun seledri dosis $500 \mathrm{mg} / \mathrm{kgbb}$ tidak berbeda nyata karena terletak pada subset yang sama. Sedangkan untuk ekstrak daun seledri dosis $250 \mathrm{mg} / \mathrm{kgbb}, 125$ $\mathrm{mg} / \mathrm{kgbb}$ dan kontrol negatif berbeda nyata karena terletak pada subset yang berbeda. Uji Duncan pada jumlah sel leukosit berbeda nyata karena kelompok uji terletak pada subset yang berbeda satu sama lain.

Selanjutnya dilakukan uji statistik Pearson Correlation untuk melihat hubungan antara peningkatan dosis ekstrak etanol daun seledri terhadap peningkatan efek imunostimulan. Dari nilai konstanta fagositosis terlihat bahwa nilai $\mathrm{p}=0,000 \quad(\mathrm{p}<0,05)$ artinya terdapat korelasi yang signifikan dan sangat kuat antara peningkatan dosis ekstrak daun seledri dengan nilai konstanta fagositosis. Sedangkan nilai $r=0,933$ yang menunjukkan nilai positif artinya besar dosis yang diberikan berbanding lurus dengan nilai konstanta fagositosis. Semakin tinggi dosis maka nilai konstanta fagositosisnya semakin besar. Dari nilai waktu paruh terlihat bahwa nilai $\mathrm{p}=0,000(\mathrm{p}<0,05)$ artinya terdapat korelasi yang signifikan dan sangat kuat antara peningkatan dosis ekstrak daun seledri dengan nilai waktu paruh. Sedangkan nilai $r=-0,880$ yang menunjukkan nilai negatif artinya besar dosis yang diberikan berbanding terbalik dengan nilai waktu paruhnya. Semakin tinggi dosis maka nilai waktu paruh semakin kecil. Dari jumlah nilai leukosit terlihat bahwa $\mathrm{p}=0,000(\mathrm{p}<0,05)$ artinya terdapat korelasi yang signifikan dan sangat kuat antara peningkatan dosis ekstrak daun seledri dengan jumlah nilai leukosit. Sedangkan nilai $\mathrm{r}=0,973$ yang menunjukkan nilai positif artinya besar dosis yang diberikan berbanding lurus dengan jumlah nilai leukosit. Semakin tinggi dosis maka jumlah nilai leukosit semakin besar.

Dari hasil penelitian dapat dilihat bahwa ekstrak daun seledri dapat menimbulkan efek imunostimulan terhadap mencit putih jantan mulai dari pemberian dosis terkecil yaitu $125 \mathrm{mg} / \mathrm{kgbb}$ hingga kontrol pembanding Stimuno Forte ${ }^{\circledR}$. Dari nilai konstanta fagositosis terlihat kecepatan proses fagositosis tercepat dari kelompok perlakuan adalah kontrol pembanding Stimuno Forte $^{\circledR}$ dilanjutkan dengan ekstrak daun seledri dosis 500 $\mathrm{mg} / \mathrm{kgbb}$ diikuti dengan dosis $250 \mathrm{mg} / \mathrm{kgbb}, 125$ $\mathrm{mg} / \mathrm{kgbb}$ dan kontrol negatif. Dari waktu paruh karbon terlihat bahwa eliminasi karbon tersingkat dari kelompok perlakuan adalah kontrol pembanding Stimuno forte ${ }^{\circledR}$ dilanjutkan dengan ekstrak daun seledri dosis $500 \mathrm{mg} / \mathrm{kgbb}$ diikuti 
dengan dosis $250 \mathrm{mg} / \mathrm{kgbb}, 125 \mathrm{mg} / \mathrm{kgbb}$ dan kontrol negatif. Dari jumlah nilai leukosit terbesar dari kelompok perlakuan adalah kontrol pembanding Stimuno forte ${ }^{\circledR}$ dilanjutkan dengan ekstrak daun seledri dosis $500 \mathrm{mg} / \mathrm{kgbb}$ diikuti dengan dosis $250 \mathrm{mg} / \mathrm{kgbb} 125 \mathrm{mg} / \mathrm{kgbb}$ dan kontrol negatif. Mekanisme terjadinya efek imunostimulan ekstrak daun seledri ini diduga karena adanya kandungan senyawa flavonoid. Senyawa flavonoid merupakan imunostimulator alami dan antioksidan untuk meningkatkan kemampuan fagositosis makrofag dengan menangkal radikal bebas yang masuk kedalam tubuh (Hasdianah dkk, 2014).

\section{SIMPULAN}

1. Ekstrak etanol daun seledri (Apium graveolens L.) dengan dosis $125 \mathrm{mg} / \mathrm{kgbb}$, $250 \mathrm{mg} / \mathrm{kgbb}$ dan $500 \mathrm{mg} / \mathrm{kgbb}$ memiliki efek imunostimulan terhadap mencit putih jantan galur Swiss Webster.

2. Peningkatan dosis ekstrak etanol daun seledri (Apium graveolens L.) dapat meningkatkan efek imunostimulan secara signifikan pada mencit putih jantan galur Swiss Webster.

\section{DAFTAR PUSTAKA}

Aldi, Y., Ogianan, N., Handayani, D. 2013. Uji Imunomodulator Beberapa Subfraksi Ekstrak Etil Asetat Meniran (Phyllanthus niruri L.) Pada Mencit Putih Jantan Dengan Metode Carbon Clearance. Prosiding Seminar Nasional Perkembangan Terkini Sains Farmasi dan Klinik, 3, 134-146.

Aribi, B., Zarizer, S., Kabouche, Z. 2013. Imunomodulatory Activity of Argania Spinosa Seeds. International Jurnal of Pharmacy and Pharmaceutical Sciences, 5, 488-491.

Djamal, Rusjdi. 2012. Kimia bahan alam: prinsipprinsip dasar isolasi dan identifikasi. Padang : Universitas Baiturrahmah.

Fitria, T., dan Saputra, O. 2016. Khasiat Daun Seledri (Apium graveolens) Terhadap Tekanan Darah Tinggi Pada Pasien Hiperkolestrolemia. Medical Journal of Lampung University, 5, 120-125.

Gunawan, S.G. 2012. Farmakologi dan Terapi Edisi 5. Jakarta : Balai Penerbit FKUI.

Hasdianah, Dewi, P., Peristiowati, Imam, S. 2014. Imunologi: Diagnosis dan Teknik Biologi Molekuler. Yogyakarta: Nuha Medika.

Khalifah, S.N., dan Lutfiah, N. 2010. Religiopsikoneuroimunologi Al-Quran Studi
Kolaborasi Terapi Al Quran dan Fungsi Otak Dalam Menghadapi Stres. Jurnal Buletin Psikologi, 18, 19-28.

Kurnianingtyas, E., Djati, M.S., Rifa, M. 2013. Aktivitas Imunomodulator Polyscias Obtusa Terhadap Sistem Imunitas Pada Bone Marrow Broiler Setelah Pemberian Salmonella thphimurium. Journal Experience Life Science, 3, 25-30.

Ohyver, Margaretha. 2013. Penerapan Metode Transformasi Logaritma Natural dan Partial Least Squares Untuk Memperoleh Model Bebas Multikolinier san Outlier. Jurnal Mat Stat, 13, 42-51.

Rahayu, S. 2017. Sehat Tanpa Obat Dengan Seledri. Yogyakarta: Rapha Publishing.

Sapri, Siswanto, E., Yulianti, A. 2017. Uji Antiinflamasi Fraksi Air Ekstrak Daun Seledri (Apium graveolens L.) Pada Mencit Jantan. Jurnal Ilmiah Ibnu Sina, 2, 60-67.

Sasmito, E., Nugroho, A.E., Sagala Y.V. 2014. Efek Penghambatan Ekstrak N-Heksana Buah Mengkudu (Morinda citrifolia L.) Terhadap Reaksi Anafilaksis Kutaneus Aktif Pada Tikus Wistar Yang Diinduksi Vaksin Hepatitis B. Traditional Medicine Journal, 19, 36-42.

Setianingsih, N., Ula, A.M., Purnamasari, R. 2017. Pengaruh Pemberian Ekstrak Metanol Daging Buah Kurma (Phoenix dactylifiera) Terhadap Jumlah Total Leukosit Embrio Mencit (Mus musculus). Prosiding seminar III. Biologi, Pembelajaran, dan Lingkungan Hidup Perspektif Interdisipliner: 111-115. Surabaya, 29 April 2017: Prodi Pendidikan BiologiFKIP.

Subowo. 2009. Imunologi Edisi III. Jakarta: Sagung Seto.

Subowo. 2014. Imunobiologi Edisi II. Jakarta: Sagung Seto.

Sukmayadi, A. E., Sumiwi S. A., Barliana M. I., Aryanti A. D. 2014. Aktivitas Imunomodulator Ekstrak Etanol Daun Tempuyung (Sonchus arvensis Linn.). Indonesian Journal of Pharmaceutical Science and Technology, 1, 65-72.

Wongtawatchai, T., Sarsutham, K., Sukketsiri, W., Tipmanee, V. Chonpathompikunlert, P. 2017. Antistress effect of Apium graveolen on rats subjected to immobilization. International Food Research Journal, 24, 1490-1499.

Zilhadia, Wiraswasti, Y., Chairul. 2012. Uji Efek Imunomodulator Katekin Gambir (Uncaria gambir Roxb.) Menggunakan Parameter 
Jurnal Penelitian Farmasi Indonesia 9(1), Juni 2020

ISSN : 2302-187X

$e$-ISSN 2656-3614

Bersihan Karbon Secara In Vivo. Jurnal

Bahan Alam Indonesia, 8, 181-186. 